\title{
The taxonomic significance of achene in the genus Ranunculus L. in Egypt
}

\author{
Azza A. Shehata \\ Botany Department, Faculty of Science, Alexandria University \\ and \\ Zaki A. Turki \\ Botany Department, Faculty of Science, Menofiya University.
}

Shehata A A. \& Turki Z. A. 2001. The taxonomic significance of achene in the genus Ranunculus L. in Egypt. Taeckholmia 21(1):15-25 .

Morphological characters of achenes for nine species of Ranunculus among $R$. sardous Crantz. is new record to the flora of Egypt. from Egypt have been investigated using light (LM) and scanning (SEM) microscopy. Carpel wall structure for some studied species has also been searched. The achene morphology showed considerable variations in shape, size, surface pattern and wall structure. The macrocharacters as well as microcharacters of achenes are discussed in relation to taxonomy and proved their significance in the distinction between the studied species. A key and SEM micrographs of achenes are provided.

Key words: Ranunculus, Ranunculaceae, morphology, Seed coat surface, seed anatomy.

\section{Introduction}

Ranunculaceae is a large family containing a number of well-known wild flowers and garden ornamentals such as aconitum, anemones, buttercups and hellebores (Heywood, 1993). Mabberley (1997) recorded 62 genera and 2450 species of the family, which are distributed throughout the world and centered in temperate and cold regions of the northern and southern hemispheres.

The genus Ranunculus is cosmopolitan including ca. 600 worldwide species (Tamura, 1995). This genus exhibits a number of archaic characters of the flower such as a more or less strongly convex receptacle, apocarpy or primary polyandry. However some more advanced characters such as differentiated perianth or nectar production at the base of the petals are also present.

Comprehensive studies have been made on the family Ranunculaceae; Santisuk (1979), Savitskii (1982), Al-Eisawi (1986), Aboel Atta et al (1999), Hosny (1994), Xuhan et al (1994), De-Caneloda et al (1995) and others.

According to Turki (1998), Ranunculus is represented in Egypt by eight species, viz. Ranunculus peltatus Scharnk, $R$. rionii Lagger, $R$. bulbosus L, R. marginatus Dum.Urville, $R$. muricatus L, $R$. arvensis L, R. asiaticus L and $R$. sceleratus L. The study revealed the importance of achene characters (their number in the fruiting head, size and shape) as diagnostic characters for the separation of the species.

According to Greuter et al. (1989) Ranunculus sardous is liable to occur in Egypt. It was recently collected by the second author (April 1999) as a new record to the 
Flora of Egypt along the irrigation canals of the newly established Burg El- Arab town. It is probably introduced with new crop plants.

Because of the potential value of the seed coat surface patterns, achenes (fruits) and pollen, SEM studies have contributed significantly to the systematic of various angiosperms; e.g. Barthlott 1981; Boesewinkle and Bouman 1984; Vasil 1993.

Accordingly the present investigations were undertaken to show how far the morphological features of achenes, especially their surface pattern, might be of identificatory value for the Egyptian Ranunculus species.

\section{Material and methods}

The investigated species were mainly obtained from the herbaria of Faculty of Science, Cairo University and Menofiya University, Egypt. The sources of the studied species are given in Table (1).

Table 1: Material used in the present study.

\begin{tabular}{|c|c|c|c|}
\hline Species & \multicolumn{2}{|c|}{ Collector \& date of collection } & Herbarium \\
\hline Ranunculus rionii Lagger & Burdet 3 & 26 VI 1908 & CAI \\
\hline R. bulbosus L. & Turki s.n. & 5 VI 1997 & MNF \\
\hline R. asiaticus L. & El. Hadidi s.n. & 13 III 1952 & CAI \\
\hline R. sceleratus L. & Turki s.n. & 20 III 1995 & MNF \\
\hline R. marginatus d'Urv. & Turki s.n. & 22 III 1995 & MNF \\
\hline R. muricatus L. & Turki s.n. & 22 III 1995 & MNF \\
\hline R. arvensis L. & Fahmy s.n. & 3 IV 1992 & CAI \\
\hline R. sardous L. & Turki s.n. & 5 III 1999 & MNF \\
\hline R. peltatus Schrank & Täckholm s.n. & & CAI \\
\hline
\end{tabular}

CAI $=$ The herbarium, Faculty of Science, Cairo University, Egypt.

MNF = The acronym of the herbarium, Faculty of Science, Menofiya University, Egypt.

The macromorphological characters of 15 achenes for each species were studied by the aid of low power stereomicroscope. Scanning electron microscopy study of the achene surface was carried out to determine the surface ornamentation of the achene wall (micromorphological characters).

In the genus Ranunculus the seed coat is undifferentiated, crushed and intermingled with the carpel wall, so the photographs were taken for achene wall (carpel wall). This phenomenon was observed in many taxa of the Ranunculaceae with an achene fruit (Corner, 1976).

Dried achenes were mounted on brass stubs and coated with a thin layer of gold using JEOL JFCL 1100E ion sputtering. Coated achenes were then examined at an accelerating voltage of $15 \mathrm{KV}$ with JEOL JSM 530P SEM at electron microscopic unit, Faculty of Science, Alexandria University.

For anatomical studies achenes were too hard to be sectioned by standard paraffin techniques, so they were softened by a mixture of 10: 3: 9 glycerol: $10 \%$ aliosol: water (for methods see Schmid \& Turner, 1977) for at least several days before 
The taxonomic significance of achene in the genus Ranunculus L. in Egypt

sectioning, then achenes were dehydrated through an alcohol series and embedded in paraffin with MP $52^{\circ} \mathrm{C}$, sections cut at 5 um in thickness were stained with Hematoxylin and Eosin, then mounted in Canada balsam. Light photomicrographs were taken with a Zeiss Photomicroscope.

Terminology concerning the description of achene surface pattern was adopted after Stearn (1966) and Barthlott (1984).

\section{Results and discussion}

\section{Macromorphological and micromorphological characters of achenes}

Macromorphological and micromorphological characters of achenes of studied species are summarized in Table (2).

\section{Ranunculus arvensis L. (Fig.1)}

Achenes strongly compressed, broadly obovate, with flattened margin, mean length 7.5 mm including $1.5 \mathrm{~mm}$ straight beak. Both faces showed tuberculated surface pattern with long and hooked spines. Anticlinal walls wavy and thick, periclinal walls convex.

\section{Ranunculus muricatus L. (Fig.2)}

Achenes compressed, elliptical with wide margins, mean length $7.5 \mathrm{~mm}$ including $3.0 \mathrm{~mm}$ deflexed beak. Both faces showed echinate pattern with long and hooked outgrowths (spines). Anticlinal walls wavy and raised, periclinal walls reticulate.

Ranunculus sardous Crantz (Fig. 3, 4) [New record to the Flora of Egypt].

Achenes ovate, mean length $2.1 \mathrm{~mm}$ including $0.3 \mathrm{~mm}$ recurved beak. Surface pattern tuberculate and papillose, minutely punctate. Anticlinal walls sinuate (u-type), thick and raised, periclinal walls flat and striate.

\section{Ranunculus marginatus d Urv. (Fig.5,6)}

Achenes compressed, obovate to orbicular with grooved margins, mean length $3.4 \mathrm{~mm}$ including $0.8 \mathrm{~mm}$ upturned beak. Surface pattern tuberculate and punctate. Anticlinal walls wavy, thick and raised, periclinal walls flat with fine stria.

\section{Ranunculus sceleratus L. (Fig.7,8)}

Achenes suborbicular to ovoid, transversely wrinkled, mean length $1.1 \mathrm{~mm}$ including $0.1 \mathrm{~mm}$ beak. Surface pattern regular with faintly rugose. Epidermal cells isodiametric. Anticlinal walls very thick, raised and straight, periclinal walls concave with rugose surfaces.
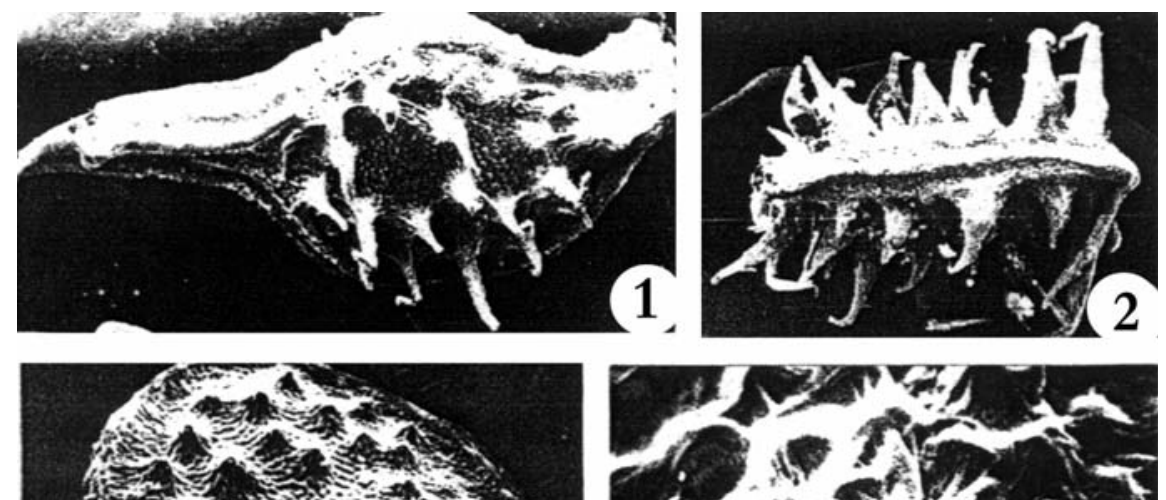
A A. Shehata \& Z. A. Turki

Figs. (1-8). Scanning electron micrographs of achene surface.

Fig. 1. Entire achene of Ranunculus arvensis (x 15), Fig. 2. Entire achene of $R$. muricatus (x 15 ), Fig. 3. Entire achene of $R$. sardous (x 50), Fig. 4. Enlarged part of achene surface of $R$. sardous (x 500), Fig. 5. Entire achene of R. marginatus (x 35), Fig. 6. Enlarged part of achene surface of $R$. marginatus (x 750), Fig. 7. Entire achene of $R$. sceleratus (x 100), Fig. 8. Enlarged surface part of achene surface of $R$. sceleratus (x 1,500).

\section{Ranunculus bulbosus L. (Fig.9, 10)}


The taxonomic significance of achene in the genus Ranunculus L. in Egypt

Achenes compressed, suborbicular, mean length $3.7 \mathrm{~mm}$ including $0.7 \mathrm{~mm}$ straight or recurved beak. Surface pattern reticulate and smooth. Epidermal cells hexagonal to tetragonal. Anticlinal walls chanelled and thin, periclinal walls flat and striated.

\section{Ranunculus rionii Lagger (Fig. 11,12)}

Achenes suborbicular, ovate, mean length up to $1.0 \mathrm{~mm}$ including $0.1 \mathrm{~mm}$ beak. Surface pattern reticulate. Epidermal cells polygonal. Anticlinal walls thick, slightly wavy and raised, periclinal walls flat with longitudinal and transversely surface.

\section{Ranunculus asiaticus L. (Fig. 13, 14)}

Achenes ovate, flat, broadly winged, mean length $3.9 \mathrm{~mm}$ including $0.9 \mathrm{~mm}$ recurved beak. Surface pattern rugose. Anticlinal walls slightly wavy, thick and raised, periclinal walls flat with fine striation and rugose texture.

\section{Ranunculus peltatus Schrank.(Fig. 15, 16)}

Achenes crescent-shape, mean length $1.4 \mathrm{~mm}$ long including $0.1 \mathrm{~mm}$ beak. Surface pattern rugose. Anticlinal walls slightly wavy, thick and raised, periclinal walls flat and rugose.

\section{Achene wall anatomy}

Three species were selected in order to investigate the nature of achene wall. The three selected species represent three different types of surface patterns:

1. Tuberculate type with hooked and long outgrowths, e.g. Ranunculus arvensis. (Fig.17,18).

2. Tuberculate type with short papillae, e.g. Ranunculus sardous. (Fig. 19).

3. Reticulate type, e.g. Ranunculus sceleratus. (Fig. 20).

According to Corner (1976) seeds of Ranunculus species are developed from unitegmic, tenuinucellate, anatropous ovules. Seeds albuminous and 1-5mm long, their testa with the indehiscent fruit pericarp is more or less unspecialized and the single integument may be entirely crushed. From our observations, seed coat (exotesta) apparently not multiplicative, outer integument is represented by a single layer of cuboidal cells with spiral and annular lignification of the radial and inner walls. With respect to achene wall structure, three zones can mainly be distinguished. In Ranunculus arvensis, achene wall consists of compact layers followed by several layers of brachysclereids, followed by three rows of thin-walled parenchyma cells. The orientation of these cells is parallel to longitudinal axis of the achene (tangentially elongated). This layer is followed by seed coat layer, which is represented in all studied species by only one layer of cells provided with spiral and annular thickenings. (Fig. 17, 18). In Ranunculus sceleratus the compact layer is followed by several rows (8-10 rows) of thin walled parenchyma cells, then one layer of macrosclereids, which is followed by seed coat and finally endosperm (Fig. 19). In Ranunculus sardous the achene wall is composed of two- three rows of brachysclereids followed by two- three rows of thin walled parenchyma cells, then the seed coat.
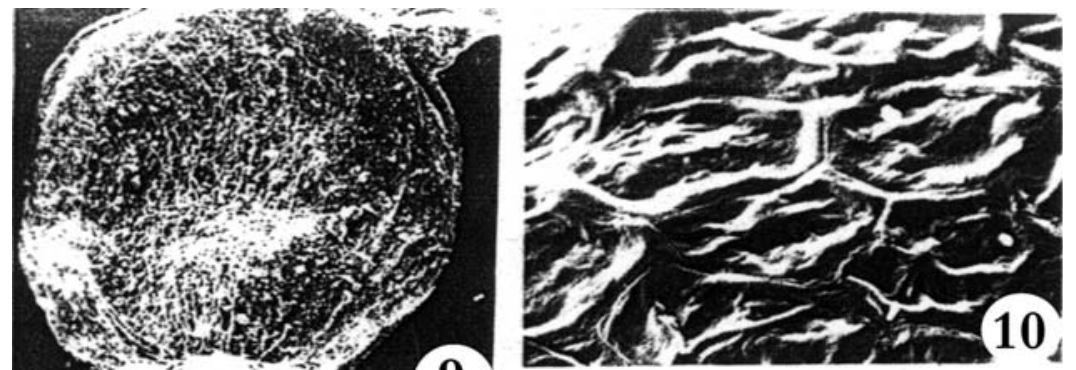
A A. Shehata \& Z. A. Turki

Figs. (9-16). Scanning electron micrographs of achene surface.

Fig. 9. Entire achene of Ranunculus bulbosus (x 50), Fig. 10. Entire achene of $R$. bulbosus (x 750), Fig. 11. Entire achene of $R$. rionii (x 100), Fig. 12. Enlarged part of achene surface of $R$. rionii (x 1,000), Fig. 13. Entire achene of $R$. asiaticus (x 15), Fig. 14. Enlarged part of achene surface of $R$. asiaticus (x 750), Fig. 15. Entire achene of R. peltatus (x 75), Fig. 16. Enlarged surface part of achene surface of $R$. peltatus (x 1,000).
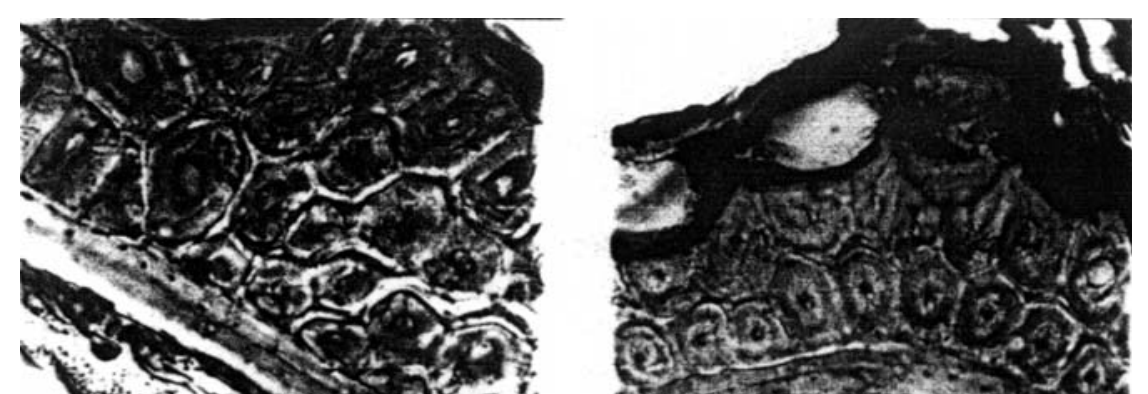
The taxonomic significance of achene in the genus Ranunculus L. in Egypt

Figs. (17-20). Scanning electron micrographs of achene surface.

Figs. 17,18. Transection of carpel of Ranunculus arvensis showing carpel wall, with three zones, seed coat and endosperm (x 40), Fig. 19. Transection of carpel of $R$. sceleratus showing achene wall (aw), seed coat (s.c.) and endosperm (end), Fig. 20. Transection of carpel of $R$. sardous showing achene wall, seed coat and endosperm (x 40).

\section{Key to species [based on achene characters]}

1.a. Achene spinose, seed coat cells isodiametric and humped. 
b. Achene surface rugose or reticulate.

2.a. Cells isodiametric, anticlinal walls straight

R. sceleratus

b. Cells elongated, anticlinal walls thick, wavy or sinuate

3.a. Periclinal walls convex and tuberculate

R. arvensis

b. Periclinal walls flat, striate or reticulate

4.a. Periclinal walls reticulate, achene elliptic, up to $7.5 \mathrm{~mm}$ long with $3.0 \mathrm{~mm}$ long beak

\section{R. muricatus}

b. Periclinal walls striate, achene ovate to orbicular, 2-3.5 mm long with 0.3$0.8 \mathrm{~mm}$ long beak

5.a. Achene up to $3.5 \mathrm{~mm}$ long including $0.8 \mathrm{~mm}$ beak

R. marginatus

b. Achene up to $2.5 \mathrm{~mm}$ long including $0.3 \mathrm{~mm}$ beak

R. sardous

6.a. Cells polygonal, anticlinal and periclinal walls striate

b. Cells elongated, anticlinal walls wavy, periclinal walls rugose....

7.a. Anticlinal walls thin, chanelled, achene up to $3.5 \mathrm{~mm}$ long including $0.7 \mathrm{~mm}$ beak

\section{R. bulbosus}

b. Anticlinal walls thin and raised, achene $0.9 \mathrm{~mm}$ long including $0.1 \mathrm{~mm}$ beak

8.a. Achene crescent-shaped, up to $1.4 \mathrm{~mm}$ long including $0.1 \mathrm{~mm}$ beak

b. Achene ovate, up to $4.0 \mathrm{~mm}$ long including $0.9 \mathrm{~mm}$ beak

R. asiaticus

Achenes of the studied species are considerably variable in shape, being crescent-shaped in $R$. peltatus, ovate to elliptic in $R$. rionii and $R$. marginatus and ovate to obovate and laterally compressed in the rest of the species.

The present work is concerned primarily with the investigation of both macrocharacters and microcharacters of achene. According to the surface pattern of achenes, studied species can be distinguished into four groups: the first group includes $R$. arvensis and $R$. muricatus which have echinate (spinose) pattern; the second group includes $R$. marginatus and $R$. sardous having tuberculate and punctate pattern; the third group includes $R$. asiaticus, $R$. peltatus and $R$. rionii, having rugate pattern and the fourth group includes $R$. sceleratus and $R$. bulbosus with reticulate and smooth surface pattern. Within each group, the species can be distinguished on the basis of other characters.

The epidermal layer has different shapes of cells: isodiametric as in $R$. sceleratus, polygonal as in $R$. bulbosus and $R$. rionii and elongated as in all other species. Anticlinal walls of the studied species range from slightly to clearly wavy appearance in five species, straight in three species and sinuate in one species as indicated in table (2). 
The taxonomic significance of achene in the genus Ranunculus L. in Egypt

From the present results, we can conclude that both macro- and microcharacters of the achene wall as well as its anatomy can provide additional characters of taxonomic significance in separation of the genus Ranunculus.

Table 2. Macro-and Micro-morphological characters of the achenes of the investigated species of Ranunculus.

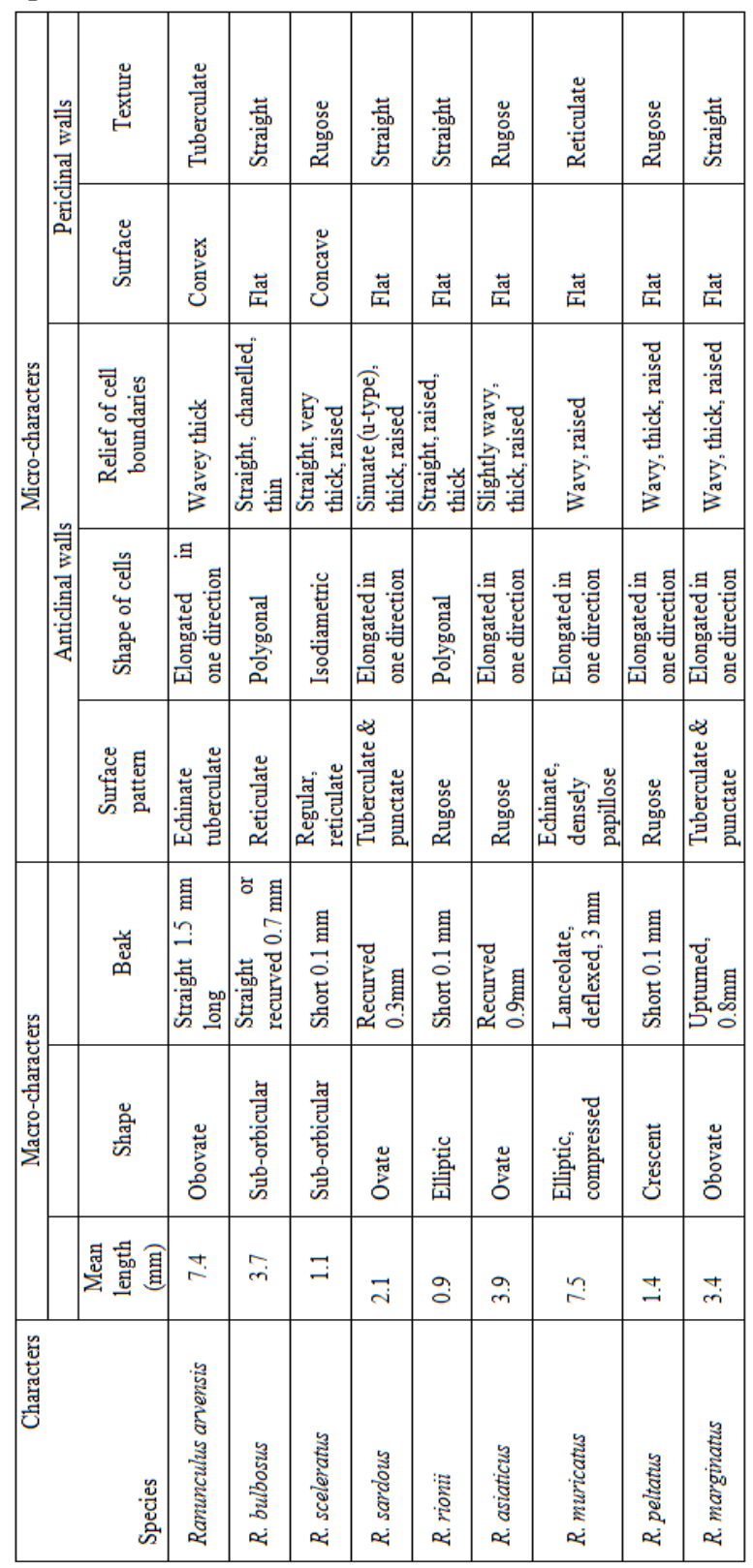




\section{Acknowledgement}

Our deepest gratitude is extended to Prof. Dr. M. N. El-Hadidi, Cairo University Herbarium, for his extended encouragment.

\section{References}

Aboel Atta A. I. I., Kamel E. A., Loutfy M. H. A. \& El-Mashad A. A. 1999. Studies on some relationships between certain species of the Ranunculaceae. Egypt $J$. Biotechnol. 6.

Al-Eisawi D. M. 1986. Pollen morphology of Ranunculaceae in Jordan. Pollen et Spores 29:311-328.

Barthlott W. 1981. Epidermal and seed surface characters of plants. Systematic applicability and some evolutionary aspects. Nordic J. Bot., 1:345-355. 1984. Microstructural features of seed surface, in Heywood, V. H. \& Moore, D. M. (eds.). Current Concepts in Plant Taxonomy. Academic Press, London.

Boesewinkel F. D. \& Bauman F. 1984. The seed structure, in B. M. Johri (ed.). Embryology of Angiosperms Springer-Verlag. Berlin Heidelberg, New York, Tokyo.

Corner E. J. H. 1976. The Seeds of Dicotyledons, vols.1\&2. Cambridge University Press, Cambridge.

De-Canelada M. E. L. \& Martinez A. J. 1995. Chromosome recount of species of the genus Ranunculus L. in the Province of Tucmman (Argintina). Lilloa. 38(2):179180.

Greuter W., Burdet H. M. \& Long G. 1989. Ranunculus L., in Med. Checklist. 4:417-441. Généve.

Heywood V. H. 1993. Flowering Plants of the World. Andromeda, Oxford Ltd.

Hosny A. I. 1994. Taxonomic significance of Ranunculaceae. J. Fac. Education, Ain Shams university, 19: 677-686.

Mabberley D. J. 1997. The Plant Book. A Portable Dictionary of the Vascular Plants. Cambridge University Press, Cambridge.

Santisuk T. 1979. A palynological study of the Tribe Ranunculae, Opera Botanica, 48:177.

Savitskii V. D. C. 1982. Morphology, classification and evolution of pollen of the Ranunculaceae. Naukova Dumaka, Kiev.

Schmid R. \& Turner M. D. 1977. Contard 70, an effective softener of herbarium material for anatomical study. Taxon 26:551-552.

15 Stearn W. T. 1966. Botanical Latin. Tomas Nelson \& Sons. Ltd. London, Edinburgh.

Tamura M. 1995. Ranunculaceae. In Engler, A. and Prantl, K., Die naturlischen Pflanzenfamilien, ed. 2, 17a IV. Berlin.

Turki Z. A. 1998. Taxonomic revision of the species of the genus Ranunculus L. in Egypt. J. Union Arab Biol. 6(B):353-364.

Vasil- eva I. M. 1993. Seed morphology and anatomic characters of seed coat in some species of the genus Aquiligia (Ranunculaceae). Botanicheskii-zhurnal. 78(4):6780. 
The taxonomic significance of achene in the genus Ranunculus L. in Egypt

Xuhan, X. and Van-Lammeren, A. A. M. (1994). The ultrastructure of seed coat development in Ranunculus sceleratus. Acta Botanica Neerland. 43 (1): 27-37. 